DOI: https://doi.org/10.11144/Javeriana.umed59-2.ihdf

\title{
Factors Associated with the Initiation of the Smoking Habit in University Students in Bogotá, Colombia
}

\section{Factores asociados al inicio del hábito de fumar en estudiantes universitarios en Bogotá, Colombia}

Received: 12/01/2017 | Accepted: 27/06/2017

\author{
Ana María Barreto Niño \\ Pontificia Universidad Javeriana, Colombia \\ Paula Andrea Bonilla Reyes \\ Pontificia Universidad Javeriana, Colombia \\ Juan Francisco Calderón Bonilla \\ Pontificia Universidad Javeriana, Colombia \\ Melissa Andrea Cantillo Avilez \\ Pontificia Universidad Javeriana, Colombia \\ Julián Alonso Viña Lopera \\ Pontificia Universidad Javeriana, Colombia \\ Hoover Quitián-Reyes ${ }^{\mathrm{a}}$ \\ Pontificia Universidad Javeriana, Colombia
}

a Correspondence: quitianh@javeriana.edu.co

\begin{abstract}
Introduction: All over the world 5.4 million people die due to tobacco related diseases per year. Considering that teenagers are highly impressionable by media in tobacco consumption, they constitute the population of interest in order to diminish the use of tobacco and the morbidity associated with its use. Objective: To identify factors associated at the beginning of tobacco consumption. Methodology: Descriptive crosssectional study using a poll created from a questionnaire on tobacco by Center of Disease Control and Prevention, with a sample of smokers, over 18, selected in the most popular smoking areas at Universidad Javeriana, Bogota - Colombia. Results: The most frequent factors related to the beginning of tobacco consumption were: Peer pressure $(34.6 \%)$, curiosity $(24.7 \%)$ and stress $(17.6 \%)$. The average starting smoking age was $14.3( \pm 1.9)$. Conclusion: The low capacity of opposing social pressure at parties and recreational events showed as the most important factor at the beginning of a smoking habit.
\end{abstract}

Keywords

smoking; undergraduate students; factors; cigarette.

\section{RESUMEN}

Introducción: En el mundo, 5,4 millones de personas fallecen al año por enfermedades relacionadas con el tabaco, y la adolescencia es una de las etapas más vulnerables para desarrollar el hábito de fumar. Objetivo: Identificar factores asociados al inicio del consumo de tabaco en los estudiantes de la Pontificia Universidad Javeriana, Bogotá. Métodos: Se aplicó una encuesta de carácter voluntario, creada a partir del

How to cite: Barreto Niño AM, Bonilla Reyes PA, Calderón Bonilla JF, Cantillo Avilez MA, Viña Lopera JA, QuitiánReyes H. Factors Associated with the Initiation of the Smoking Habit in University Students in Bogotá, Colombia. Univ. Med. 2018;59(2). doi: https://doi.org/10.11144/Javeriana.umed59-2.ihdf cuestionario de consumo de tabaco desarrollado por el Center of 
Desease Control and Prevention, a estudiantes de pregrado, mayores de edad, reclutados en los lugares de la Universidad más concurridos por fumadores. Resultados: La edad promedio de inicio del consumo en la muestra fue de 14,3 años $( \pm 1,9)$. Los factores más frecuentes fueron presión social $(34,6 \%)$, curiosidad $(24,7 \%)$ y estrés $(17,6 \%)$. Conclusión: La poca resistencia a la presión del entorno es la principal causa del inicio del hábito de fumar. Palabras clave

fumar; estudiantes; factores; cigarrillo.

\section{Introduction}

The consumption of tobacco cigarettes is a mechanism that serves to strengthen bonds and form new relationships (1); however, it is a public health problem; tobacco smoke causes $90 \%$ of all lung cancers and is a major risk factor for strokes, heart attacks and some oral diseases (2). Around the world, around 5.4 million people die every year from diseases related to tobacco consumption (3), and it is estimated that if the trend continues, in the next five years tobacco will cause 50\% more deaths than HIV/AIDS (4).

The National Health Survey, conducted in Colombia by the Ministry of Health and Social Protection, reported that in 2007 the prevalence of cigarette smoking in the population between 18 and 69 years of age was around 12.8\%; this figure, although high, is lower than that registered in 2011 in other Spanish-speaking countries $(5,6)$, such as Spain $(37 \%)$, Mexico $(36.4 \%)$, Argentina $(34,7 \%)$ and Venezuela (31.6\%) (7).

Despite the national efforts, the anti-smoking laws (8) have not managed to eradicate smoking, although they have reached a significant reduction: "From a prevalence of smoking of $21.4 \%$ in 1993 , it went to $18.9 \%$ in 1998 , and from this to $12.8 \%$ in 2007 " (5). A relevant aspect in this regard is that Bogota, the capital of Colombia, where most anti-smoking projects are carried out, has one of the highest prevalences in the country, $15.9 \%$, which is higher than the national average.

In the case of smokers of school age "tobacco consumption increases considerably with age [...]; among schoolchildren aged 11 to $12,2.8 \%$ report that they have used this substance in the last month, a figure that rises to $17.4 \%$ among students aged 16 to 18 " (5). For this reason, this population is among the main objectives of tobacco companies to increase their income $(9,10)$.

Due to the above, since 2003, the Pontificia Universidad Javeriana (PUJ) has intensified projects promoting healthy habits among the students. In terms of tobacco consumption, the university created the Clinic to Quit Smoking, "an interdisciplinary service that uses the model of stages of behavioral change to provide treatment to those who wish to quit smoking", in order to reduce the prevalence (11).

Several factors associated with the initiation of cigarette smoking have been documented in the literature $(12,13,14)$. This article explores these factors among students of the PUJ, because identifying the most common factors is a necessary input to formulate policies, plans and programs to prevent the appearance of new smokers and promote the cessation of the habit.

\section{Materials and methods}

A non-probabilistic sample was taken according to criteria. Since smoking is generally done in the company of others, and in order to reach the greatest number of smokers, with the help of the security personnel, we identified the places where smokers congregate within the campus (Figure 1) and we determined that the hours of greatest congestion at these places are between 12:00 m. and 2:00 p.m. In October 2014, a pollster went to each of these places for five consecutive business days, at the aforementioned times. Due to the way in which the sample was taken and the resulting size, we did not perform analyzes to determine if the differences between groups were statistically significant, because these results would not be conclusive. 
Figure 1.Sections and number of respondents in the smoking points of the Pontificia Universidad Javeriana during the five days of data collection

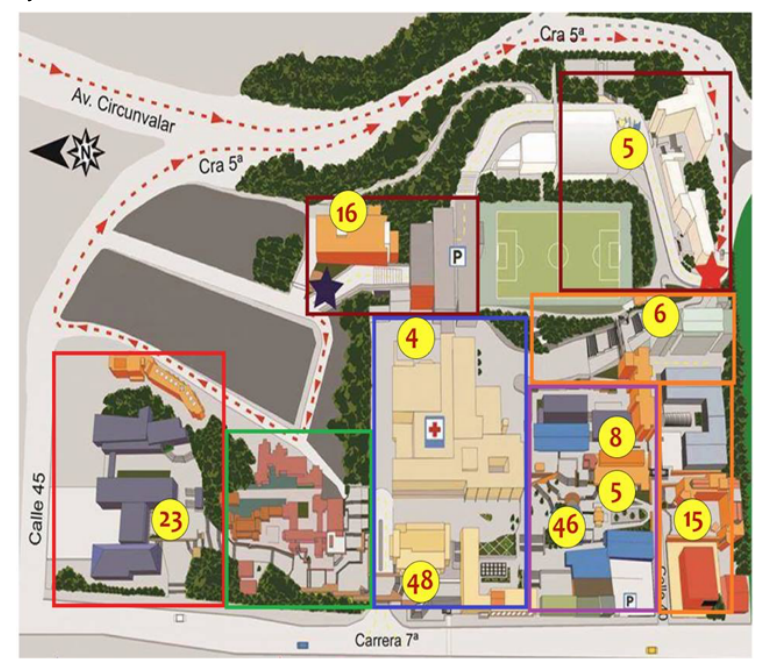

To collect the information, a self-administered questionnaire of 26 questions was used, 15 were taken from the Encuesta del consumo de tabaco entre los hispanos/latinos de 18 años de edad o más: cuestionario totalmente en español (Survey on Tobacco Consumption Among Hispanics/Latinos 18 Years of Age or Older: Questionnaire Entirely in Spanish) (15), used by the Center of Disease Control and Prevention for a study of the Latin population in the United States; the rest of the questions were created by the authors of this article to characterize the student population under study.

The survey was voluntary and included only smokers of legal age who were active students who completed an informed consent. In this the implications of the study were briefly explained and they were informed that the information of the interviewee would remain anonymous and out of reach of third parties.

For the analysis of the resulting data, the subjects were divided into two categories: those who had tried to quit smoking, defined as not smoking for a day or more for that purpose, and those who had not tried.

\section{Results}

In total, 176 completed surveys were collected and 3 partially completed, which were excluded. Table 1 summarizes the characteristics of the surveyed population. $28.4 \%$ of smokers interviewed were women; the average age was 20.3 years $( \pm 1.7) ; 83.5 \%$ said they were heterosexual, and $80.1 \%$ were single and were living with their family. Regarding the economic variables, $82.5 \%$ were in stratum 4 or higher, and $14.8 \%$ had some paid work.

Table 1.Characteristics of the population interviewed

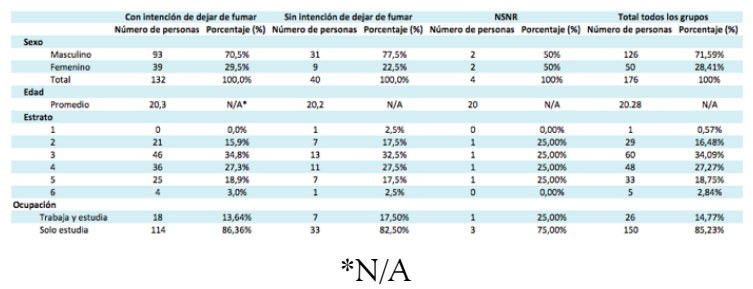

Information was collected from students of 25 different undergraduate courses. The career with the greatest participation was Law (12.9\%), followed by Administration, Architecture and Industrial Design, with approximately $10.5 \%$ each. Regarding the frequency of consumption, $47.2 \%$ said that they smoked every day, followed by $36.9 \%$, who smoked five or six days a week.

$75 \%$ of the respondents had tried to quit smoking, or were in the process of quitting, $22.7 \%$ reported that they had never tried; the remaining percentage did not answer the question, and no differences were found in the sociodemographic data of these two groups.

Among those who have tried to stop smoking or are in the process of quitting, the main cause for them to start smoking was social pressure (39.1\%), followed by curiosity (24.6\%). $82.6 \%$ said that the first time they smoked were in the company of a friend, and $9.1 \%$, in the presence of a family member. Parties $(48.5 \%)$ or recreational environments $(24.2 \%)$ were the places where they started, being mainly in a happy mood $(43.18 \%)$ or excited $(32.6 \%)$. They reported that at that time they experienced dizziness $(56 \%)$ or cough $(37.9 \%)$, and $47 \%$ were smoking every day. 
In contrast, those who stated that they had never tried to stop smoking attributed their initial consumption mainly to curiosity $(25 \%)$ or stress (22.5\%). 12.5\% were alone when they smoked for the first time: $70 \%$ did so when they were happy or excited, $32.5 \%$ did not experience any discomfort such as dizziness or cough, and $52.5 \%$ said they were smoking every day. Table 2 contains the results for each of the elements analyzed.

Table 2.Main results per group

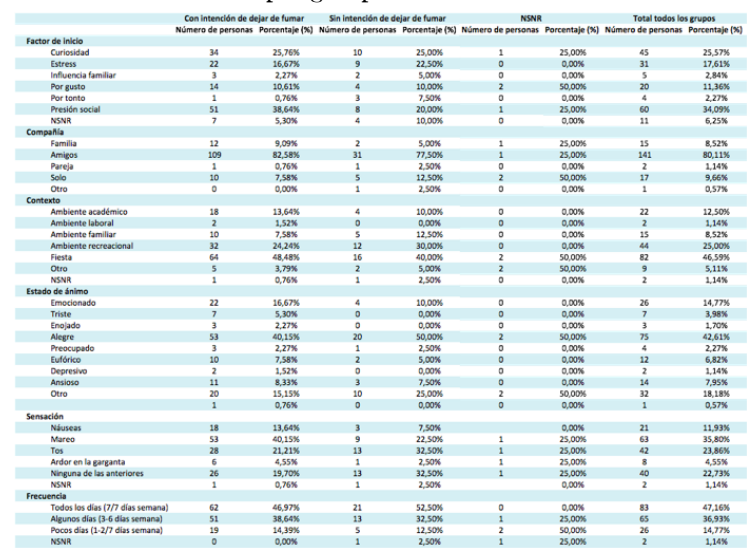

\section{Discussion}

Regardless of the region, a common element among the studies that assess the prevalence of tobacco use in the young population is that mainly men manifest having this addiction; the average age at which they started is around 13 years $(16,17,18,19)$. Perhaps this early start is the reason why it is common for the young population, taking into account the remaining years before reaching their life expectancy, to express the intention to quit smoking in the near future (20), in order to avoid harmful consequences for health.

Regarding the reasons for the initiation of tobacco use, this study agrees with those frequently reported in the literature: in general, they are related to the construction of the personality during adolescence such as the feeling of insecurity (16), curiosity (21) and low selfesteem (19).

The main weakness of the study is the way in which the sample was collected, because it does not ensure that the data are representative of the entire academic population of the PUJ. However, the results are consistent with other studies conducted in the country with similar populations, which would allow us to think that the conclusions are not entirely invalid for our context. For example, in Bogotá (22) evidence was found that university spaces offer an environment conducive to consumption; in the city of Manizales (23) it was found that consumption peaks coincide with the periods of highest academic demand, and in Cali (24), that both the gender and the faculty to which the students belong are factors associated with an increased cigarette consumption.

On the other hand, the way in which the questions were asked allowed people to answer without pressure that induced them to give socially desirable answers, such as affirming that they have tried to quit smoking; because of this, there is no reason to think that the results in this regard are not reliable.

Given that this is a public health problem recognized throughout the world, similar studies have been conducted in different Spanishspeaking countries, such as Guatemala (25) and Mexico (26). It has been found that the main reasons why medical students smoke are stress, the imitation of teachers and fashion, and that the age of initiation is inversely related to the probability of quitting smoking; no evidence was found of a relationship with the socioeconomic level, or effects of restriction policies, such as the limitation to the sale of single cigarettes.

\section{Conclusion}

Mainly, psychological factors and vulnerability to the environment create in adolescents the tendency to begin smoking $(27,28)$. In addition, it seems that there are differences that determine the course of the addiction. The evidence suggests that those who initiate consumption more out of curiosity than due to social pressure tend to adopt the habit without considering the possibility of quitting. Other studies have suggested similar conclusions 
related to personality, since for the strengthening of the smoking habit, a personality characterized by fear of the disapproval of others is more favorable than one that seeks acceptance (29).

Because of the complexity and the multiple factors that favor the initiation of cigarette smoking, as well as the consequences for health and for the consumption of resources of the health systems, it is necessary to intervene in the young population (30). Unfortunately, there is no clarity as to which strategies are effective to reduce the vulnerability of the young population to the environment that surrounds them, since the mass media (31) and the incentive programs (32) have failed in effectively preventing the initiation of cigarette smoking and in stopping the habit in young people.

There is also uncertainty about policies to reduce cigarette consumption. The most studied measure has been the creation of taxes, and although consumption has responded to price increases, it seems that the reduction is not enough to effectively combat the problem $(28,30,33,34)$.

The most important contribution of this exploratory study is that, since no elements were found to suggest that there are differences between the behavior towards cigarette smoking of the students of the PUJ and the young population of the rest of the country and even of other latitudes, it is suggested to resort to measures that have been effective for other cities or nations, although it is necessary to evaluate our own alternatives, it will be possible to take advantage of the joint effort or the one made in other research centers, to advance in the elimination of cigarette smoking in the university population.

From the perspective of the authors of this article, as active students of the Faculty of Medicine, after analyzing the phenomenon in the university context, a constant presence of susceptibility of the students to their environment is identified as a determining factor in the initiation and in the habitual consumption of cigarettes. We believe that, in addition to continuing to promote healthy extracurricular activities (19), the university should use advertising campaigns that are present in the classrooms and in the physical and virtual spaces in which the academic community interacts, so that not smoking be considered part of the identity of the PUJ community, and especially of the Faculty of Medicine.

\section{References}

1. Rubio Monteverde H, Rubio Magaña A. Breves comentarios sobre la historia del tabaco y el tabaquismo. Rev Inst Nac Enfermedades Respir. 2006;19(4):297-300.

2. Petersen PE. Global policy for improvement of oral health in the 21 st century-implications to oral health research of World Health Assembly 2007, World Health Organization. Community Dent Oral Epidemiol. 2009;37(1):1-8.

3. Mathers CD, Loncar D. Projections of global mortality and burden of disease from 2002 to 2030. Samet J, editor. PLoS Med. 2006 Nov;3(11):e442.

4. Carson KV, Verbiest EM, Crone MR, Brinn MP, Esterman AJ, Assendelft JW, et al. Training health professionals in smoking cessation. Cochrane Database Syst Rev. 2012 May 16; (5):CD000214.

5. Ministerio de Salud y Protección Social. Socialización del informe final de evaluación de necesidades para la apliacion del Convenio Marco de Control del Tabaco: cifras oficiales para Colombia. Bogotá: Ministerio; 2007 p. 10-2.

6. Ministerio de la Protección Social, Colciencias, Pontificia Universidad Javeriana, Centro de Proyectos para el Desarrollo, Sistemas Especializados de Información. Encuesta Nacional de Salud 2007. Bogotá, Colombia; 2009.

7. Fundadeps. Atlas mundial de la salud [Internet]. 2014 [cited 2014 Oct 1]. Available from: http:// www.atlasdelasalud.org/ver.aspx? indicador $=$ Hombres mayores de 15 años fumadores(\%). 
8. Rivera Rodríguez DE, Niño Bogoya A. ABC de la Ley Antitabaco (Ley 1335 de 2009) [Internet]. 2009. Available from: https://w ww.minsalud.gov.co/Documentos $\% 20 \mathrm{y} \% 2$ OPublicaciones/ABC\%20DE\%20LA\%20L EY\%20ANTITABACO.pdf.

9. Rodríguez Naranjo C, Caño González A. Autoestima en la adolescencia: análisis y estrategias de intervención. Int J Psychol Psychol Ther. 2012;12(3):389-403.

10. Organización Panamericana de la Salud, Organización Mundial de la Salud, Alma-Ata, Mpower. La industria tabacalera te atrapa joven [Internet]. [Cited 2014 Aug 24]. p. 2. Available from: http://contralasadicciones.files.word press.com/2012/05/leer-mc3a1s7.pdf.

11. Becerra Martinez NA, Alba Talero LH, Vivas Prieto JM, Cañón Muñoz MA, Luna Guerrero C, Castaño Mora IP. Modelo de una clínica para dejar de fumar en la Pontificia Universidad Javeriana, Bogotá, Colombia. Aten Fam. 2010;18(4):87-90.

12. Caballero-Hidalgo A, González B, Pinilla J, Barber P. Factores predictores del inicio y consolidación del consumo de tabaco en adolescentes. Gac Sanit. 2005;19(6):440-7.

13. Nebot M, Tomás Z, Ariza C, Valmayor S, Mudde A. Factores asociados con la intención de fumar y el inicio del hábito tabáquico en escolares: resultados del estudio ESFA en Barcelona. Gac Sanit. 2002;16(2):131-8.

14. Marrón Tundidor R, Pérez Trullén A, Clemente Jiménez ML, Herrero Labarga I. Factores asociados con la intención de fumar y el inicio del hábito tabáquico en escolares: resultados del estudio ESFA en Barcelona. Prev Tab. 2003;5(4).

15. Centers for Disease Control and Prevention. Encuesta del consumo de tabaco entre los hispanos/latinos de 18 años de edad o más: Cuestionario totalmente en español [Internet]. 2010 p. 55. Available from: https://www.cdc.gov/tobacco/data_st atistics/surveys/hispanic_latino_ats_guide/ pdfs/qxSpan.pdf.
16. Memetovic J, Ratner PA, Gotay C, Richardson CG. Examining the relationship between personality and affect-related attributes and adolescents' intentions to try smoking using the Substance Use Risk Profile Scale. Addict Behav. 2016;56:36-40.

17. Mbatchou Ngahane BH, Atangana Ekobo $\mathrm{H}$, Kuaban C. Prevalence and determinants of cigarette smoking among college students: a cross-sectional study in Douala, Cameroon. Arch Public Health Arch Belg Santé Publique. 2015;73:47.

18. Sharma S, Singh M, Lal P, Goel S. Predictors of Tobacco Use among Youth in India: GATS 2009- 2010 Survey. Asian Pac J Cancer Prev APJCP. 2015;16(17):7535-40.

19. Fakhfakh R, Jaidane I, Hsairi M, Ben Hamida AM. [Cigarette smoking initiation among Tunisian adolescents: Risk and protective factors]. Rev Dépidémiologie Santé Publique. 2015;63(6):369-79.

20. Camara A, Balde D, Sidibé S, Barry SM, Camara B, Barry AM, et al. [Smoking and related factors among college students in Dixinn, Guinea]. Santé Publique Vandoeuvre-Lès-Nancy Fr. 2015;27(4):585-91.

21. Hong R-M, Guo S-E, Chen M-Y. The Experiences of Tobacco Use among SouthWestern Taiwanese Adolescent Males. Int $\mathrm{J}$ Environ Res Public Health. 2015;12(9):10522-35.

22. Novoa-Gómez MM, Barreto I, Manuel Silva L. Consumo de cigarrillo y prácticas culturales en contextos universitarios. Rev Latinoam Psicol. 2012;43(1):97-110.

23. Castaño Castrillón JJ, Páez Cala ML, Pinzón Montes JH, Sánchez Castrillón GA, Torres Ríos JM, Valencia Gómez MA, et al. Estudio descriptivo sobre tabaquismo en la comunidad estudiantil de la Universidad de Manizales. Rev Fac Med. 2007;56(4):1-13.

24. Tafur LA, Ordóñez G, Millán JC, Varela JM, Rebellón P. Prevalencia de tabaquismo en estudiantes recién ingresados a la Universidad Santiago de Cali. Colomb Médica. 2006;37(2):126-32. 
25. Cheesman Mazariegos SS, Suárez Lugo N. Tabaquismo en estudiantes de medicina de la Universidad de San Carlos de Guatemala. Rev Cuba Salud Pública. 2015;41(1):18-32.

26. Reynales-Shigematsu LM, Vásquez-Grameix $\mathrm{H}$, Lazcano-Ponce E. Encuesta Mundial de Tabaquismo en Estudiantes de la Salud, México 2006. Salud Pública Mex. 2007;49(2):194-204.

27. Roohafza H, Heidari K, Alinia T, Omidi R, Sadeghi M, Andalib E, et al. Smoking motivators are different among cigarette and waterpipe smokers: The results of ITUPP. J Epidemiol Glob Health. 2015;5(3):249-58.

28. Fulmer EB, Neilands TB, Dube SR, Kuiper NM, Arrazola RA, Glantz SA. Protobacco media exposure and youth susceptibility to smoking cigarettes, cigarette experimentation, and current tobacco use among US Youth. PloS One. 2015;10(8):e0134734.

29. Copeland AL, Spears CA, Baillie LE, McVay MA. Fear of fatness and drive for thinness in predicting smoking status in college women. Addict Behav. 2016;54:1-6.

30. Trapl ES, Yoder LD, Frank JL, Borawski EA, Sattar A. Individual, parental, and environmental correlates of cigar, cigarillo, and little cigar use among middle school adolescents. Nicotine Tob Res Off J Soc Res Nicotine Tob. 2016;18(5):834-41.

31. Sowden AJ. Mass media interventions for preventing smoking in young people. En: The Cochrane Collaboration, editor. Cochrane Database of Systematic Reviews [Internet]. Chichester, UK: John Wiley \& Sons; 1998 [cited 2017 Oct 17]. Available from: http://doi.wiley.com/10.1002/146518 58.CD001006.

32. Thomas D, Johnston V. Incentives for preventing smoking in children and adolescents. En: The Cochrane Collaboration, editor. Cochrane Database of Systematic Reviews [Internet]. Chichester, UK: John Wiley \& Sons; 2010 [cited 2017 Oct 17]. Available from: http://doi.wiley.com/10.1002/146518 58.CD008645.

33. Daugbjerg C, Svendsen GT. Designing green taxes in a political context: From optimal to feasible environmental regulation [Internet]. University of Aarhus, Aarhus School of Business, Department of Economics; 2001. Available from: http://ide as.repec.org/p/hhs/aareco/2001_017.html.

34. Glomm G, Kawaguchi D, Sepulveda F. Green taxes and double dividends in a dynamic economy [Internet]. Center for Applied Economics and Policy Research, Economics Department, Indiana University Bloomington; 2006. Available from: http://i deas.repec.org/p/inu/caeprp/2006017.html. 